\title{
Cytotoxic Activities of Fractions from Dioscorea bulbifera L. Chloroform and Methanol Extracts on T47D Breast Cancer Cells
}

\author{
Rinto Muhammad Nur ${ }^{1}$, Laurentius Hartanto Nugroho ${ }^{2 *}$
}

\section{Rinto Muhammad Nur', Laurentius Hartanto Nu- groho ${ }^{2 *}$}

'Faculty of Fisheries and Marine Science, Universitas Pasifik Morotai, JIn. Siswa Darame, Kec. Morotae Selatan, Kab. Morotae, Maluku Utara, INDONESIA.

${ }^{2}$ Faculty of Biology, Universitas Gadjah Mada, Jln. Teknika Selatan, Sekip Utara, Yogyakarta, INDONESIA.

Correspondence

\section{Laurentius H Nugroho}

Department of Tropical Biology, Universitas Gadjah Mada, JIn. Teknika Selatan, SekipUtara, Yogyakarta, INDONESIA.

Phone no: +62 81328055317

E-mail: hartantonugroho2005@ugm.ac.id History

- Submission Date: 03-08-2017;

- Review completed: 31-08-2017;

- Accepted Date: 13-09-2017

DOI : 10.5530/pj.2018.1.7

Article Available online http://www.phcogj.com/v10/i1

\section{Copyright}

(c) 2018 Phcog.Net. This is an openaccess article distributed under the terms of the Creative Commons Attribution 4.0 International license.

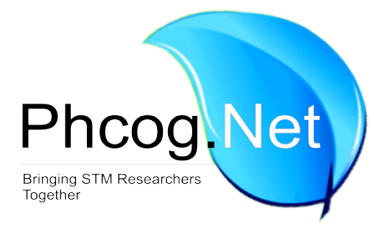

\begin{abstract}
Objective: To elucidate cytotoxic activity of fractions from chloroform and methanol extracts of $D$. bulbifera organs onT47D breast cancer cells. Method: The vegetative organs of $D$. bulbifera were extracted gradually using chloroform and methanol. Cytotoxicity tested on T47D cells using MTT Assay. The most toxic extract was fractioned by vacuum liquid chromatography (VLC) followed by thin layer chromatography (TLC). The extract and fractions potential were tested on the Vero cells using the same method as cancer cells. The most toxic fraction was analyzed using TLC followed by the application of various spray reagents for the identification of active compound. Results: The chloroform extract of the $D$. bulbifera leaves was the highest cytotoxic on T47D cells $\left(I C_{50} 115.63 \pm 86.01 \mu \mathrm{g} / \mathrm{mL}\right)$. Moreover, the cytotoxicity test on the combined fractions of leaves chloroform extract showed that fraction 5 (F5) and fraction 6 (F6) were the most toxic fractions compared to those of other fractions. The $I C_{50}$ of both fractions were $14.55 \pm 8.62$ and $7.12 \pm 4.43 \mu \mathrm{g} / \mathrm{mL}$ respectively. However, Its were very weak compared to those of cancer medicine (Doxorubicin) with the $\mathrm{IC}_{50}$ was $0.04 \pm 0.02 \mu \mathrm{g} / \mathrm{mL}$. Potential fractions were not toxic against Vero cells with IS $>10$. The active compounds in those fractions were alkaloid and terpenoid. Conclusion: Chloroform extract of the D. bulbifera leaves had the highest cytotoxic effect on T47D cells. Potential fractions were not toxic against Vero cells. The active compounds in those fractions were alkaloid and terpenoid.

Key words: Cytotoxicity, Secondary metabolites, D. bulbifera, T47D, MTT Assay.
\end{abstract}

\section{INTRODUCTION}

Dioscorea bulbifera L. is a member of Dioscoreace utilized as a source of food and traditional medicine in Indonesia. Dioscorea bulbifera L. known able to act as an antidiabetic, ${ }^{1-3}$ antimicrobial, ${ }^{4,5}$ antiinflammatory, ${ }^{6}$ antioxidant, ${ }^{7}$ antitumor, ${ }^{8-11}$ and anticancer. ${ }^{7,12}$ Currently, a lot of researches have been done to discover and develop anticancer compounds. Several studies reported that D. bulbifera had cytotoxic activity. ${ }^{13}$ The cytotoxic activity of $D$. bulbifera due to its secondary metabolites contents. Secondary metabolites content in plants or plant organs varied among each other. Secondary metabolites could be extracted using organic solvents such as chloroform and methanol. ${ }^{14}$ The current research to day is focusing on alternative medicines on cancer due to the increases of cancer death rate every year especially in developing countries. One type of deathly cancer in the world is breast cancer. ${ }^{15}$ Therefore, it is necessary to study the potency of D. bulbifera particularly as anti-cancer agents. The current research aimed to investigate the toxicity of various fractions from chloroform and methanol extracts of Dioscorea bulbifera L. organs on breast cancer T47D cells and the identification of toxic compounds group as an early research in the finding of anti-cancer drug.

\section{MATERIALS AND METHODS}

\section{Sample Collection}

Samples of Dioscorea bulbifera L. organs (tuber, bulb, stem and leaf) were collected from the village of Kaiyasa, North Maluku Province, Indonesia in September 2015. Taxonomic identification of the plant was performed at Plant Systematic Laboratory, Faculty of Biology, Universitas Gadjah Mada, Yogyakarta Indonesia. The herbarium was deposited in the same laboratory. The materials were dried in the air space while covered with a black cloth for 3 to 4 days continued by powdering using a blender. The fine powder was then packed in airtight container to avoid the effect of humidity and stored at room temperature.

\section{Sample Extraction}

Sample was macerated using chloroform and methanol. $200 \mathrm{~g}$ of powder was macerated using $1000 \mathrm{~mL}$ chloroform and kept for $48 \mathrm{~h}$ at room temperature. The extract was then filtered. The dregs were macerated many times using chloroform until filtrate was clear. The extract was then combined and dried using a fan. The dregs were dried and macerated again using methanol. The same method of chloroform extraction was applied. The extraction 
was also done for the mixture of all plant organs using chloroform and methanol. The same method as well as those of each organ was applied. Therefore, it was resulted in eight kinds of extracts.

\section{Cell Culture and MTT assay for the plant extracts}

T47D and Vero cell lines were obtained from Laboratories of Parasitology, Faculty of Medicine, Universitas Gadjah Mada, Yogyakarta, Indonesia. Cells were grown in RPMI 1640 medium supplemented with 10 \% FBS and $2 \%$ penicillin/streptomycin. Cells were cultured and propagated at $37^{\circ} \mathrm{C}$ in a $\mathrm{CO}_{2}$ incubator with $5 \% \mathrm{CO}_{2}$ in a humidified atmosphere. After confluent, cells were ready for the treatment.

Cytotoxicity test of plant extracts against T47D breast cancer cells using MTT assay was conducted following a previous procedure. ${ }^{7}$ A volume of $100 \mu$ suspension of T47D cell line culture containing $1.5 \times 104$ cells was filled in each well of 96-wells microplates. Plant extracts with a volume ranging from 50 to $400 \mu \mathrm{g} / \mathrm{ml}$, with the interval of $50 \mu \mathrm{g} / \mathrm{ml}$ were added to the cell culture. Four replicates for each treatment were applied. The treated cell culture was then incubated for $24 \mathrm{~h}$ on $37^{\circ} \mathrm{C}, 5 \% \mathrm{CO}_{2}$. At the end of incubation time, the culture media was discarded, and the cells were washed using PBS. A volume of $110 \mu \mathrm{MTT}$ solution was then added into each well, followed by incubating the cells on $37^{\circ} \mathrm{C}$ and $5 \%$ $\mathrm{CO}_{2}$ for $4 \mathrm{~h}$. Upon completion of incubation, $100 \mu \mathrm{l}$ of stopper reagent SDS $10 \%$ was added and kept for overnight. The cell absorbance was read using ELISA reader on $\lambda=595 \mathrm{~nm}$. The absorbance results were analyzed by calculating the percentage of cell viability using the following formula:

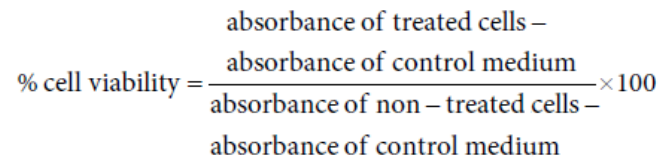

\section{Fractionation of potential plant extracts using Vacuum Liquid Chromatography}

Fractionation of a potential plant extract was conducted according to previous procedure ${ }^{8}$ using vacuum liquid chromatography (VLC). The stationary phase used in this process was silica gel GF254, and the mobile phase was a series of solvent with various polarities as those used in TLC. The column was arranged by placing the filer paper in the bottom layer followed by silica gel $60 \mathrm{GF} 254(10 \mathrm{~g})$. The top layer was the mixed of potential extract and silica gel $(4: 10 \mathrm{w} / \mathrm{w})$ covered by filter paper. Fractionation process was done by slowly pouring the solvent to the column followed by vacuuming process. The solution resulted from this process was collected in a porcelain container. After being fully air-dried, then the weight of each fraction was measured.

\section{MTT assay for the fractions}

The cytotoxicity of potential fractions against T47D cancer cells were carried out using a standard procedure $\mathrm{e}^{7}$ as described in the previous section.

\section{Phytochemical Analysis of Potential Extract and Fractions}

Potential extract and fractions were further identified for their group of compounds such as alkaloid, flavonoid, and terpenoid using TLC which were reacted with the reagent spray. ${ }^{16}$ The samples of $10 \mathrm{mg}$ potential extract or fractions were diluted in $1000 \mu \mathrm{L}$ solvent. Stationary phase used was silica gel 60 F254.

\section{Identification of alkaloids}

The TLCchamber wasfilled and saturated with mobilephasenamely toluene: ethyl acetate: diethyl amine (7:2:1). Using millimeter pipette, the extract and fractions were spotted on the TLC plate in about $0.5 \mathrm{~cm}$ from the margin. The standard compound used was quinine in ethanol $(10 / 1 \mathrm{w} / \mathrm{v})$. The plate was then put in the TLC chamber and keep until the samples run near the opposite margin ofTLC plate. The following process was taking out the TLC plate from the TLC chamber and left it until dried. The plate was then observed and sprayed with reagent dragendorf. The same color as the standard compound indicated the presence of alkaloids.

\section{Identification of flavonoids}

The same method as the identification of alkaloid was applied in the identification of flavonoid. However, the standard compound used was quercetin in ethanol $(10 / 1 \mathrm{w} / \mathrm{v})$, the mobile phase was hexane: ethyl acetate: formic acid (6:4:0.2) and sprayed compound was sitroborate. The plate was observed and sprayed with sitroborate and then heated in oven at $105^{\circ} \mathrm{C}$ for $15 \mathrm{~min}$. A yellow color in UV $\lambda 366 \mathrm{~nm}$ indicated the presence of flavonoids.

\section{Identification of terpenoids}

Terpenoid was identified using the same method as the identification of alkaloid. However, the current test used thymol in ethanol (10/1 w/v) as a standard compound, and the mobile phase was hexane: ethyl acetate (93:7) and sprayed compound was isoaldehyde sulfate acid. When the spot was dried, the plate was observed and then sprayed with anisaldehide sulfate acid and then heated in oven at $105^{\circ} \mathrm{C}$ for $15 \mathrm{~min}$. A red-purple color indicated the presence of flavonoids.

\section{Statistical Analysis}

All data were collected from at least three independent experiments. $\mathrm{IC}_{50}$ were analyzed by Probit-Regression using Microsoft Office Excel. Data are presented as mean \pm standard deviation (SD), and were analyzed by ANOVA followed by Duncan's Multiple Range Test comparison. Differences were considered statistically significant at $\mathrm{p}<0.05$.

\section{RESULTS}

\section{Extraction of $D$. bulbifera $L$. vegetative organ's}

The results of extraction indicate that the methanol extraction produce more yield than those of chloroform. Based on plant organs, bulb produced the highest yield (11.56\%) followed by tuber $(11.03 \%)$, stem $(9.09 \%)$ and leaf $(6.27 \%)$ Table 1 . It is mean that D. bulbifera $\mathrm{L}$. vegetative organs contain more polar compound than those of semi-polar compounds, moreover, among the vegetative organs, bulb contain more polar compound compared to those of other plant organs.

\section{Extract cytotoxicities of $D$. bulbifera $L$. vegetative organs}

The results of cytotoxicity test indicate that the cytotoxic activity of chloroform extract against T47D cells was higher than those of the methanol extract. The morphological changes of T47D cells after treated with extracts of D. bulbifera L. vegetative organ could be seen in Figure 1. Chloroform extracts of leaf (CEL) performed the highest cytotoxic activity with the $\mathrm{IC}_{50}$ was $115.63 \mu \mathrm{g} / \mathrm{mL}$ Table 2 .

\section{Fractionation of a potential extract and the cytotoxic activity against T47D Cells}

In this study, extract used in fractionation was CEL $\left(\mathrm{IC}_{50} 115.63 \mu \mathrm{g} / \mathrm{mL}\right)$. The extract was fractionated with 12 kind combinations of eluent. The twelve fractions of each extract were separated by TLC with the mixture of chloroform: ethyl acetate (10:1) as a mobile phase. The similar profile 

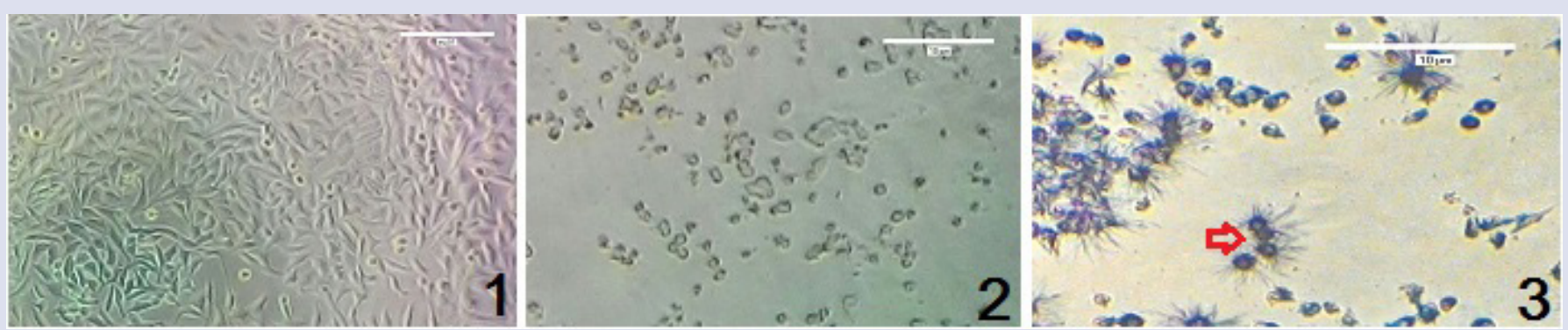

Figure 1: The morphological changes of T47D cells before and after the treatment observed using inverted microscope. 1) Control cells. The cells were confluent and sticking together; 2) The cells were treated with the methanol extract of $D$. bulbifera bulbs at a concentration of $1000 \mu \mathrm{g} / \mathrm{mL}$. Cells population was declining, the cells seem loose and the morphology were changed; 3) After the cells were MTT assayed and incubated for 4h. The arrow indicated the forming of fromazan fiber in survived cell.

Table 1: Extract and yield of D. bulbifera L. vegetative organ.

\begin{tabular}{cccccc}
\hline Organ & Solvent & Extract Code & Extract Weight $\mathbf{( g )}$ & The Yield (\%) & Extract Colors \\
\hline \multirow{2}{*}{ Tuber } & Chloroform & CET & 2.22 & 1.11 & Yellowish brown \\
& Methanol & MET & 19.84 & 9.92 & Reddish brown \\
\multirow{3}{*}{ Bulb } & Chloroform & CEB & 2.64 & 1.32 & Yellowish brown \\
& Methanol & MEB & 20.47 & 10.24 & Reddish brown \\
\multirow{3}{*}{ Stem } & Chloroform & CES & 1.84 & 0.92 & Blackish green \\
& Methanol & MES & 16.33 & 8.17 & Blackish green \\
\multirow{2}{*}{ Leaf } & Chloroform & CEL & 4.94 & 2.47 & Blackish-yellow-green \\
& Methanol & MEL & 7.59 & 3.80 & Blackish green \\
\hline
\end{tabular}

Note: weight of sample was $200 \mathrm{~g}$ for each organ of the plant. Yield = (weight of extract/weight of sample) x 100\%

Table 2: The IC $C_{50}$ value of $D$. bulbifera $L$. organ extracts against T47D cells.

\begin{tabular}{ccccc}
\hline Solvet & Plant Organs & Extract Codes & IC $_{50}$ Values $(\mu \mathrm{g} / \mathrm{mL})^{*}$ & \\
\hline Cloroform & Tuber & CET & $372.14 \pm 41.06$ & B \\
& Bulb & CEB & $414.33 \pm 29.99$ & B \\
& Stem & CES & $352.25 \pm 39.09$ & B \\
& Leaf & CEL & $115.63 \pm 86.01$ & A \\
Methanol & Mix & CEM & $285.90 \pm 41.76$ & B \\
& Tuber & MET & $2235.32 \pm 523.52$ & C \\
& Bulb & MEB & $1207.68 \pm 259.57$ & C \\
& Stem & MES & $585.50 \pm 73.73$ & B \\
& Leaf & MEL & $1601.99 \pm 266.75$ & C \\
& Mix & MEM & $6057.27 \pm 3822.73$ & D \\
\hline
\end{tabular}

Note: Numbers followed by same letter are not significantly different; \pm SD; $\mathrm{n}=3 ; \mathrm{p}<0.05$.

of fraction chromatogram was combined resulted 6 fractions combinations Table 3. The cytotoxic activity of combined fraction was tested to get the most cytotoxic combined fraction. Cell lines used for the cytotoxic test of combined fraction was T47D and the fraction concentrations used were $400,200,100,50$ and $25 \mu \mathrm{g} / \mathrm{ml}$. The cytotoxicity results of six fractions can be seen in Table 4.

\section{The cytotoxicity of the most potential extract and fractions against Vero Cells}

The test aims to evaluate the effect of the most potential extract and fractions against normal cells (Vero cells). Testing of the most potential extract and factions against Vero cells were done using about 10 times higher concentration than those of the $\mathrm{IC}_{50}$ value against T47D cells. The value of $\mathrm{IC}_{50}$ extract and potential fractions against T47D and Vero cells were then used to determine the Selectivity Index (SI) Table 5.

\section{Identification of Compound group in Potential Fractions}

The identification of bioactive compound in potential fractions of D. bulbifera leaves chloroform extract shows that F5 contains alkaloid and terpenoid, while F6 contains terpenoid. There were no flavonoids in both fractions Table 6, Figure 2. 
Table 3: The composition of combined fractions of $D$. bulbifera leaf chloroform extract and the yield after fractions combining.

\begin{tabular}{ccc}
\hline Combined Fraction & Fraction composition & Fraction weight $(\mathbf{g})$ \\
\hline F1 & Fraction 1 & 0.06 \\
F2 & Fraction 2 and 3 & 1.75 \\
F3 & Fraction 4, 5 and 6 & 0.23 \\
F4 & Fraction 7 & 0.18 \\
F5 & Fraction 8, 9 and 10 & 0.23 \\
F6 & Fraction 11 and 12 & 0.05 \\
\hline
\end{tabular}

Table 4: $\mathrm{IC}_{50}$ value of combined factions from $D$. bulbifera leaf chloroform extract against T47D cells.

\begin{tabular}{cc}
\hline Combined Fraction & $\mathrm{IC}_{50}$ value $(\mu \mathrm{g} / \mathrm{mL})$ \\
\hline F1 & $75.60 \pm 6.17$ \\
F2 & $494.55 \pm 65.56$ \\
F3 & $52.11 \pm 3.49$ \\
F4 & $71.56 \pm 8.92$ \\
F5 & $14.97 \pm 8.62$ \\
F6 & $7.74 \pm 4.43$ \\
Doxorubicin & $0.04 \pm 0.02$ \\
\hline
\end{tabular}

Note: \pm SD; $\mathrm{n}=3 ; \mathrm{p}<0.05$.
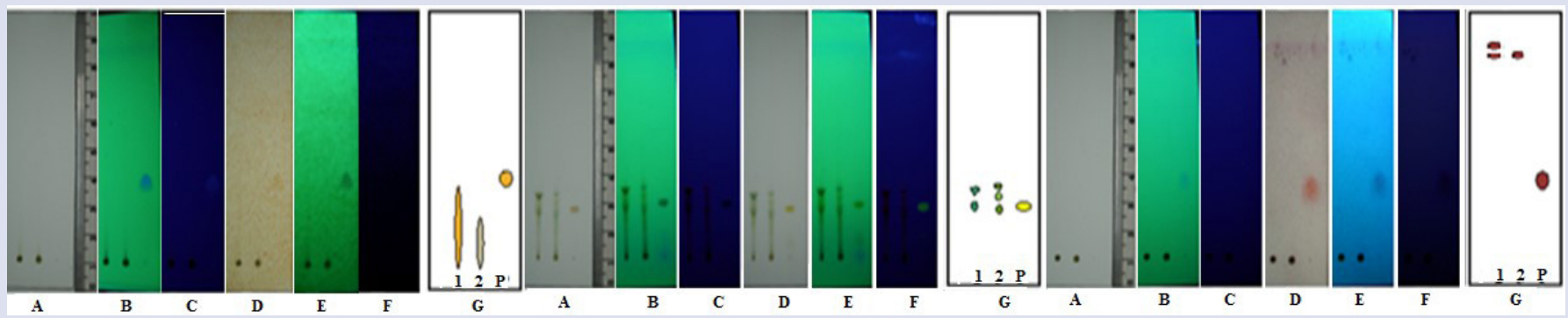

Figure 2: The chromatogram of potential fraction. Left hand reader = identification of alkaloid; middle = identification of flavonoid; right hand reader $=$ identification of terpenoid. $1=\mathrm{F} 5 ; 2=\mathrm{F} 6 ; \mathrm{P}=$ standard compound. $\mathrm{A}=$ visible light observed before spraying with spray reagent; $\mathrm{B}=\lambda 254 \mathrm{~nm} \mathrm{UV}$ rays before spraying; $C=\lambda 366 \mathrm{~nm}$ UV rays before spraying; $D=$ visible light after spraying; $E=254 \mathrm{~nm}$ UV rays after spraying; $F=\lambda 366 \mathrm{~nm} U V$ rays after spraying; $G$ = illustrated patches. The same patches colors between sample and the standard compound in the illustration showed positive result.

\section{DISCUSSION}

Among other organs, bulb and tuber produced a high yield. Its means that both organs accumulated more secondary metabolites compared to other organs. Moreover, the most yield were obtained from methanol solvent. It indicated that the compounds of secondary metabolite of $D$. bulbifera vegetative organs were mostly polar compounds. It was reported that the yield of $D$. bulbifera tubers methanol extract $(22.03 \%)$ was higher than those of chloroform extract (8.82\%). ${ }^{17}$ Obtained extract then were tested for their cytotoxic activity. The results indicated that chloroform extract had higher cytotoxic activity ( $\mathrm{IC}_{50} 115.63$ to 414.33 $\mu \mathrm{g} / \mathrm{mL}$ ) than those of methanol extract $\left(\mathrm{IC}_{50} 585.50\right.$ to $6057.27 \mu \mathrm{g} / \mathrm{mL}$ ). Chloroform is a solvent that can extract nonpolar compound such as terpenoid. Diosbulbsin B (a class of compounds terpenoids) of D. bulbifera significantly decreased the weight tumors of sarcoma (S180) and liver tumors (H22) in mice. ${ }^{11}$ Among the chloroform extracts, CEL performed the most toxic extract $\left(\mathrm{IC}_{50} 115.63\right)$ compared to those of other extracts. It indicated that the most toxic compound against T47D cell were in the leaf of D. bulbifera or may be many compounds able to act synergistically among each other while many compounds in the other organs acted antagonistic.

Considering that the extracts of plant organ contains many metabolites and the compounds able to act synergistically or antagonistically each other, the extraction process was followed by fractionation. Extracts used for fractionation was CEL. Fractionation processes with VLC method used 12 eluent combinations. Fractionation result was monitored using TLC with chloroform: ethyl acetate (10:1) as a mobile phase. The fractions with similar chromatogram profile were merged, resulted in $6 \mathrm{com}$ bined fractions for the test of cytotoxic activity. Cytotoxicity test results showed that 5 fractions (F1, F3, F4, F5 and F6) had cytotoxic activities due to its $\mathrm{IC}_{50}$ were less than $100 \mu \mathrm{g} / \mathrm{mL}$. As determined by the National Cancer Institute (NCI) that the fraction with cytotoxic activity if the frac-
Table 5: The Selectivity Index (SI) value of $D$. bulbifera extract and fraction potentials.

\begin{tabular}{|c|c|c|c|}
\hline \multirow[t]{2}{*}{ Material } & \multicolumn{2}{|c|}{$\mathrm{IC}_{50}(\mu \mathrm{g} / \mathrm{mL})$} & \multirow[t]{2}{*}{ SI } \\
\hline & T47D & Vero & \\
\hline CEL & $103.87 \pm 86.01$ & $384.66 \pm 76.15$ & 3.70 \\
\hline F5 & $14.55 \pm 8.62$ & $286.61 \pm 110.42$ & 19.70 \\
\hline F6 & $7.12 \pm 4.43$ & $231.56 \pm 29.84$ & 32.52 \\
\hline
\end{tabular}

Note: $\pm \mathrm{SD} ; \mathrm{n}=3 ; \mathrm{p}<0.05$.

Table 6: The identification of compound groups in the potential fractions of $D$. bulbifera leaves chloroform extract.

\begin{tabular}{cccc}
\hline Compounds & Material & $\begin{array}{c}\text { Observation } \\
\text { Result }\end{array}$ & $\mathrm{R}_{\mathrm{f}}$ Value \\
\hline Alkaloid & F5 & + & 0.32 \\
Flavonoid & F6 & - & - \\
& F5 & - & - \\
Terpenoid & F6 & - & - \\
& F5 & + & $0.95 ; 1.0$ \\
& F6 & + & 0.95 \\
\hline
\end{tabular}

tions have $\mathrm{IC}_{50}$ less than or the same as $100 \mu \mathrm{g} / \mathrm{mL} .{ }^{18}$ While the threshold set for natural materials that will be developed as an anticancer is $\mathrm{IC}_{50} \leq$ $50 \mu \mathrm{g} / \mathrm{mL} .{ }^{19}$ However, the cytotoxic activity of factions were very weak compared to those of doxorubicin (cancer medicine) since the medicine $\mathrm{IC}_{50}$ was $0.04 \pm 0.02 \mu \mathrm{g} / \mathrm{mL}$. To know the effect of fractions on normal cell, the fractions were tested to Vero cell. From the result, it can be understood that the only CEL who had SI less than 5 . It means that the fraction 5 and 6 were selective because both fractions had selectivity index more or same as 5 . Its mean that the materials were toxic to cancer cell but 
the materials were not toxic to normal cell. ${ }^{20}$ It has been reported that ethyl acetate fraction of $D$. bulbifera significantly reduce the weight of sarcoma tumor (S180) and liver tumor (H22) in mice. ${ }^{21,11}$ Moreover, the fractions F5 and F6 (ethyl acetate: methanol) were continued for the identification of its compound groups. The identification of bioactive compounds in potential fractions show that alkaloid was found in fraction F5 while terpenoid were found in fraction F5 and F6. Previous research reported that Dioscorea bulbifera contained diosbulbsin B, E, F and $\mathrm{G}^{22}$, nor clerodane ${ }^{23}$ known as diterpenes and alkaloids $(0,37 \%){ }^{24}$ Similar results were also found in Dendobrium lasianthera and Arachnis flos-aeris which were the active compounds against T47D cancer cells were terpenoids. ${ }^{25}$ Its means that alkaloid and terpenoids in the F5 reduce the cytotoxic activity of the fraction, means that alkaloid work antagonistic with terpenoid, thus reduce the cytotoxic activity compared to F6 which only contained terpenoid.

\section{CONCLUSION}

Chloroform and methanol extracts of D. bulbifera vegetative organ had cytotoxic activity against breast cancer (T47D). Leaf chloroform extract performed the higher cytotoxic activity $\left(\mathrm{IC}_{50} 115.63 \mu \mathrm{g} / \mathrm{mL}\right)$ compared to those of other organs. Combined fractions of F5 and F6 with the ethyl acetate: methanol eluent performed the higher cytotoxic activity against breast cancer (T47D) compared to those of other fractions. The $\mathrm{IC}_{50}$ of both fraction were 14.55 and $7.12 \mu \mathrm{g} / \mathrm{mL}$ respectively. The potential fractions has cytotoxic activity against T47D cells but it was not toxic to Vero cells with SI $>10$. The secondary metabolites compound which were identified in the potential fraction were terpenoids and alkaloids.

\section{ACKNOWLEDGEMENT}

The author expresses many thanks to Directorate General for Higher Education Republic of Indonesia for the financial support provided by Pra S2 and S2 Scholarship Program for T3 Regions in Indonesia and thankful to Ishak Manilet for providing D. bulbifera samples.

\section{CONFLICT OF INTEREST}

No conflict of interest associated with this work.

\section{ABBREVIATIONS USED}

ANOVA: Analyses of Variant; F5: Faction 5; F6: Fraction 6; CEB: Chloroform Extract of Bulbs; CES: Chloroform Extract of Stem; CEL: Chloroform Extract of Leaf; CET: Chloroform Extract Tubers; ELISA reader: Enzyme-linked immunosorbent assay; GF254: Silica gel coated with flourescent indicator F254; MEB: Methanol Extract of Bulbs; MEL: Methanol Extract Leaf; MES: Methanol Extract of Stem; MET: Methanol Extract of Tuber; MTT: 3-(4,5-dimethylthiazol-2-yl)-2,5-diphenyltetrazolium bromide; RPMI 1640 medium: Roswell Park Memorial Institute; SDS: Sodium DodesilSulfat; T3 region: Terluar, Terdepan, Tertinggal (Indonesia); TLC: Thin Layer Chromatography; UV: Ultra Violate; VLC: Vacuum Liquid Chromatography.

\section{REFERENCES}

1. Ghosh S, Ahire M, Patil S, Jabgunde A, Dusane MB, Joshi BN, et al. Antidiabetic Activity of Gnidia glauca and Dioscorea bulbifera: Potent Amylase and Glucosidase Inhibitors. Research Article. Evidence-Based Complementary and Alternative Medicine. 2011;2012:1-10.

2. Okon JE, Ofeni AA. Antidiabetic Effect of Dioscorea bulbifera on Alloxan
Induced Diabetic Rats. Research Article. CIBTech Journal of Pharmaceutical Sciences. 2013;2(1):14-9:(5)

3. Rêgo TS, Ash LS, Pessoa L, Feijó MBS, Leite J, Dos-Santos AS, et al. The intake of Yam (Dioscorea bulbifera Linn) attenuated the hyperglycemia and the bone fragility in female diabetic rats, Original/Alimentos funcionales. Nutrición Hospitalaria. 2014;29(2):370-5.

4. Teponno RB, Tapondjou AL, Gatsing D, Djoukeng JD, Abou-Mansour E, Tabacchi R, et al. Bafoudiosbulbins $A$, and $B$, two anti-salmonellal clerodane diterpenoids from Dioscorea bulbifera L. var sativa. Phytochemistry. 2006;67(17):1957-63.

5. Ghosh S, Patil S, Ahire M, Kitture R, Kale S, Pardesi K, et al. Synthesis of silver nanoparticles using Dioscorea bulbifera tuber extract and evaluation of its synergistic potential in combination with antimicrobial agents. International Journal of Nanomedicine. 2012;7:483-6.

6. Mbiantcha M, Kamanyi A, Teponno RB, Tapondjou AL, Watcho P, Nguelefack TB. Analgesic and Anti-Inflammatory Properties of Extracts from the Bulbils of Dioscorea bulbifera L. var sativa (Dioscoreaceae) in Mice and Rats. Research Article. Evidence-Based Complementary and Alternative Medicine. 2010;2011:1-9.

7. Chen X, Wu S, Zeng X, Jiang X, Chen X, Yuan J, et al. Antioxidant and SGC-7901 Cell Inhibition Activities of Rhizoma Dioscoreae bulbiferae Ethanol Extracts. African Journal Traditional Complement Alternative Medicine. 2013;10(5):261-6.

8. Gao H, Kuroyanagi M, Wu L, Kawahara N, Yasuno T, Nakamura Y. AntitumorPromoting Constituents from Dioscorea bulbifera L. in JB6 Mouse Epidermal Cells. Biological and Pharmaceutical Bulletin. 2002;25(9):1241-3.

9. Gao H, Hou B, Kuroyanagi M, Wu L. Constituents from anti-tumor-promoting active part of Dioscorea bulbifera L. in JB6 mouse epidermal cells. Asian Journal of Traditional Medicines. 2007;2(3):104-9.

10. Cui $\mathrm{H}$. Antitumor activity and possible mechanism of crude polysaccharides from Dioscorea bulbifera $L$. on the mice bearing U14 cervical carcinoma. Advanced Materials Research. 2012;(560 561):374-9

11. Wang J, Ji L, Branfordwhite CJ, Wang Z, Shen K, Liu H, et al. Antitumor activity of Dioscorea bulbifera L. rhizome in vivo. Fitoterapia. 2012;83(2):388-94.

12. Yu ZL, Liu XR, Mc-Culloch M, Gao J. Anticancer effects of various fractions extracted from Dioscorea bulbifera on mice bearing HepA. China Journal of Material Medical. 2004;29(6):563-7.

13. Liu H, Chou G, Wu T, Guo Y, Wang S, Wang C, et al. Steroidal Sapogenins and Glycosides from the Rhizomes of Dioscorea bulbifera. Journal of Natural Products. 2009;72(11):1964-8.

14. Tiwari P, Kumar B, Kaur M, Kaur G, Kaur H. Phytochemical screening and Extraction: A Review. International Pharmaceuticals Sciences. 2011;1(1):98-106.

15. Anonymous. Global Cancer Facts and Figures. $3^{\text {rd }}$ Edition. Atlanta: American Cancer Society (ACS); 2015.61p.

16. Harbourne JB. Phytochemical methods: A guide to modern technique of plant analyses. Second edition. Campman and Hall. London. 1984

17. Wahyuningsih MSH, Syarif RA, Suharmi S, Murini T, Saputra F, Adiguno SW. Selektivitas ekstrak terpurifikasi daun Tithonia diversifolia ((Hemsley) A. Gray) terhadap sel HeLa. Traditional Medicine Journal. 2013;18(1):22-8.

18. Subhash C, Sarla S, Abhay MP, Anoop B. Nutritional Profile and Phytochemical Screening of Garhwal Himalaya Medicinal Plant Dioscorea bulbifera. International Research Journal of Pharmacy. 2012;3(5):289-94.

19. Malek SNA, Phang CW, Ibrahim H, Norhanom AW, Sim KS. Phytochemical and cytotoxic investigations of Alpinia mutica rhizomes. Molecules. 2011;16(1):583-9

20. Syarifah MMS, Nurhanan MY, Haffiz JM, Ilham AM, Getha K, Asyiah O, et al. Potential anticancer compound from Cerbera odollam. Journal of Tropical Forest Science. 2011;23(1):89-96

21. Awik PDN, Sukardiman, Fadjri HT. Uji sitotoksisitas dan efek ekstrak spons laut Aaptos suberitoides terhadap sel kanker serviks (HeLa) secara in vitro. ITS 2011. [2016;15]. Available from: http://digilib.its.ac.id.

22. Ashajyothi V, Pippalla RS, Satyavati D. Dioscorea bulbifera, A Review. International Journal of Pharmacy and Technology. 2012;4(2):2157-63.

23. Liu H, Chou G, Guo Y, Ji L, Wang J, Wang Z. Nor clerodane Diterpenoids from Rhizomes of Dioscorea bulbifera. Phytochemistry. 2010;71(10):1174-80.

24. Subasini U, Thenmozhi S, Sathyamurthy D, Vetriselvan S, Rajamanickam GV, Dubey GP. Pharmacognostic and Phytochemical Investigations of Dioscorea bulbifera. International Journal of Pharmacy and Life Science. 2013;4(5):2693-700.

25. Nugroho LH, Pratiwi R, Susandarini R, Wardoyo ERP, Megawati O, Handayani S Isolation of Bioactive Compounds from Two Orchid Species and Preliminary Test of Their Cytotoxicity Against T47D Breast Cancer Cells. International Journal of Pharmacognosy and Phytochemical Research. 2016;8(1);150-5. 
GRAPHICAL ABSTRACT

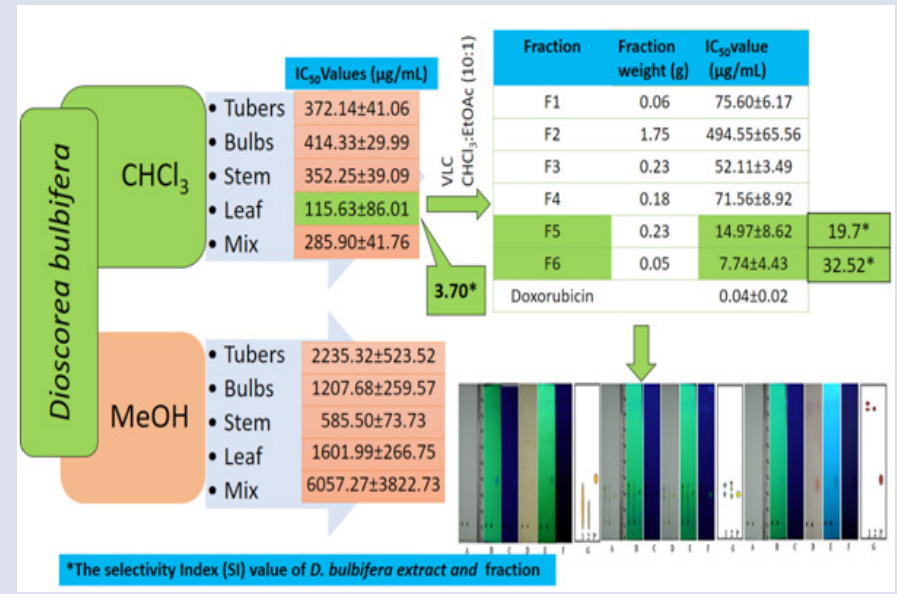

\section{SUMMARY}

- Chloroform extract of the D. bulbifera leaves had the highest cytotoxic effect on T47D cancer cells.

- Fraction 5 (F5) and F6 were the most toxic compared to those of other chloroform extract fractions.

- The F5 and F6 activity $\left(\mathrm{IC}_{50}: 14.55 \pm 8.62\right.$ and $\left.7.12 \pm 4.43 \mu \mathrm{g} / \mathrm{mL}\right)$ were very weak compared to those of cancer medicine (Doxorubicin) $\left(\mathrm{IC}_{50}: 0.04 \pm 0.02 \mu \mathrm{g} / \mathrm{mL}\right.$ ).

- Potential fractions were not toxic against Vero cells.

- The active compounds in the fractions were alkaloid and terpenoid.

\section{ABOUT AUTHORS}

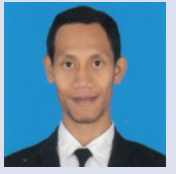

Rinto Muhammad Nur: Is a young Lecture at the Faculty of Fisheries and Marine Science, Universitas Pasifik Morotai, Jln. Siswa Darame, Kec. Morotae Selatan, Kab. Morotae, Maluku Utara, Indonesia. His current research interest is bioactivity of various plant especially indigenous plant at Maluku island or Indonesia in general.

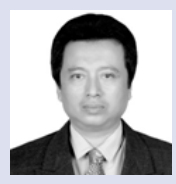

Laurentius Hartanto Nugroho: Is a Professor at the Tropical Biology Department, Faculty of Biology, Universitas Gadjah Mada, Yogyakarta, Indonesia. He is a Professor in the field of Plant anatomical structure and secondary metabolites. He has experience in the area of plant anatomical structure, plant histochemistry, plant metabolite profiling, and the activities of various plant secondary metabolites in various cancer cells.

Cite this article: Nur RM and Nugroho LH. Cytotoxic Activities of Fractions from Dioscorea bulbifera L. Chloroform and Methanol Extracts on T47D Breast Cancer Cells. Pharmacog J. 2018;10(1):33-8. 